\title{
Negus Ezana: Revisiting the Christianisation of Aksum
}

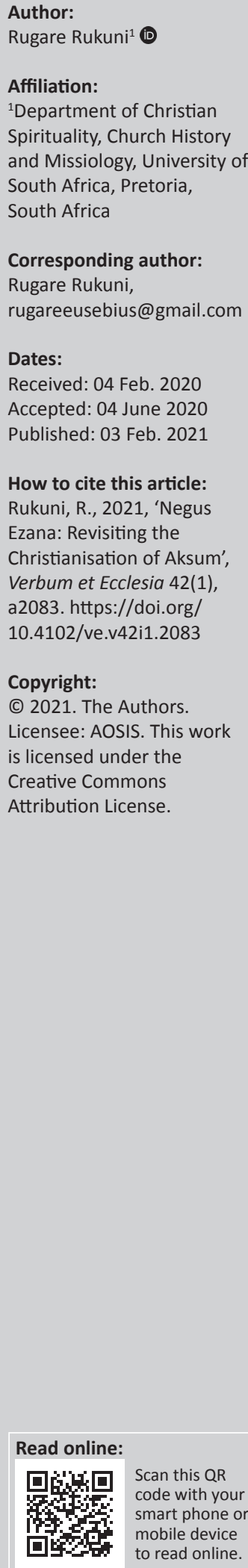

The Christianisation of Ethiopia is decoded within the reign of Ezana. The person of Ezana as a real-time figure and within the context of then Aksumite religious-cultural and political dynamics creates the background of the narrative for Ethiopian Christianity. In a revised study as a follow-up to the investigations of the dating of Ezana, revisiting his conversion, the study attempts to locate the Negus within the complex of then emergent Christian orthodoxy continuum whilst assigning due regard to the Judaic background enveloping Aksumite religion and antiquity. This attempt adds to the development of an integrated approach to church history, where the integrated narrative of Aksumite Christianity will be composite to the complete documentation of early Christianity. The investigation was accomplished through a multi-approach, whilst the main method was document analysis, as commensurate with the nature of the study, cultural historiography and the archaeology of religion was dually engrained. A review of the conversion and reality of Ezana in tangent with the recorded accounts of Ethiopian Christianity, when exerted through reference to archaeological, epigraphic and numismatic evidence, enhances a comprehensive narrative on the recorded inceptions of Ethiopian Christianity. The conversion of Ezana and the narrative of Frumentius' ordination as the first Abuna though an account mainly ascribed to narratives by ecclesiastical historians; is an event that can be substantiated through the re-examination of archaeologicalepigraphical data. Therefore, Aksumite Christianity should be composite to wholistic Christian narratives as paralleling the manner Vandal episodes and eastern Christianity are duly noted.

Intradisciplinary and/or interdisciplinary implications: Whilst the article takes the main form of a historical review of Ethiopian Christianity's origins, there are inferences to biblical studies and archaeological establishments. The main methodology takes the form of a document analysis in the form of comprehensive literature review which also includes references to epigraphy.

Keywords: Christian History; Ethiopia; Ezana; early Christianity; Judaic-Christian connection.

\section{Introduction}

Ezana's conversion: The development of a political-religious tradition.

The Christianisation of Ethiopia hinges upon the persona of Negus Ezana, the recorded first Christian Negus. This is parallel to how Judaic tradition is assigned to Menelik and Queen Makeda as per the Kebra Naghast. Significantly Ezana represents the inception of Ethiopian Christianity, whilst latter emperors such as Kaleb signify the existence of Christian statecraft, all of which builds up the momentum of the Ethiopian narrative. As the case with the narrative of Makeda and Menelik, the event of Ethiopian Christianisation is examined for authenticity using archaeology, epigraphy and other studies. The purpose of the study is to ascertain the reality of the conversion of Ezana as per historical, archaeological and epigraphical evidence.

\section{Methodology}

There will be a systematic examination of documents through document analysis (cf. Bowen 2009:27). Dually so as to emphasise the cultural nature of the study, cultural historiography was implied (Danto 2008:17). As an adaptation of cultural historiography, an evaluation of narratives through a comprehensive lens of enculturation and self-definition was done (Rukuni 2018:156). The archaeology of religion was a guiding method as it is relevant to the question at hand (Insoll 2004:59; Yamauchi 1972:26). 


\section{Christianisation of a Nation}

The advent of Christianity within Ethiopia in the 3rd and 4th century is a fact established within secular and religious histories. The narrative is a derivate from Ethiopic and nonEthiopic sources (Kaplan 1982:28). A revisionist attempt at the account and the deductions formerly made regarding the Christianisation of Ethiopia in the conversion of Ezana is merited. Kaplan derived an aggregated account in the perspective of Theodoret, Rufinus and Ethiopic sources in sync with the survey and discussion of sources done by Petrides (1971:81-99). There are notable elements within the narrative that tie in with the reality of maritime travel. Frumentius and Aedesius were Syrian captives taken from a plundered ship; they found themselves in the court of the king (Kaplan 1982:28). This inceptionally highlights the influence of Syrian-Eastern Christianity within the Ethiopian Christian cultural matrix, thereby implying an elongated relationship, one that was analogous to time. Whilst there can be a discussion on 1st century CE apostolic Christianity engaging Ethiopia (Rukuni \& Oliver 2020), the reference to Syrian-Eastern Christians introducing their aspect of Christianity to Ethiopia at this respective moment is a reference to the $3 \mathrm{rd}$ and 4 th century CE.

The narrative regarding Frumentius and Aedesius reads more as a legend, yet there are certain entrenched undertones that enhance the deductions regarding the religious-political complex of Ethiopia. Frumentius and Aedesius are said to have been enrolled into the service of the King; therefore, even in their unfortunate circumstances, they were still perceived with high esteem it seems (Theodoret Hist. Eccles 1.22, ed. Schaff 1885b:127; Rufinus, Historia Ecclesiastica 10.9-10; Amidon 1997:18-20). This implies that they were not taken as low-ranking slaves but rather as nobles; this resonates with the purposed Thomine contact with Gundaphar (Acts Thom 2:22-27; ed. James 1924:9-11), as a skilled craftsman eligible for royal service. Whilst Aedesius was taken in as a cupbearer, Frumentius was honoured with the service of treasurer and secretary. Whilst it is essential to substantiate the Ethiopian enslaving practice within the aforementioned respect, there are implied allusive features in the legend. These possibly derive from the influence of Judaic and apostolic Christian tradition on Ethiopia (Piovanelli 2014:690). Firstly, the reference to Aedesius as a cupbearer reads more as the appointment of biblical Nehemiah an important exilic leader of the Jews in the time of the Persian dominance of the BCE era (Neh 2-13). Nehemiah's influence with the Persian monarch Cyrus ultimately saw the return of the Jews to the promised land. Nehemiah held the position of cupbearer with the Persian monarch yet; he incited a conversation that was definitive of the orient from which he originated, as there was imperial policy that was crafted in favour of his ethnicity (Neh 2-13). In an equally significant parallel, the appointment of Frumentius as treasurer and secretary of the monarch resonates with the Lukan-Acts account of the Ethiopian Eunuch who met Phillip (Ac 8:26-38). Therefore, the legend has some Judaic-Christian connotations which perhaps could be an index for a more substantial reality concerning the advent of Christianity in Ethiopia.

Upon the death of the monarch Frumentius and Aedesius governed at the instruction of the queen regent pending the maturity of Negus Ezana (Jones \& Monroe 1935:26-27). This claim appears relatively unusual; however, it sheds light on the symbiotic relationship between the Ethiopian aristocracy and the clerical establishment, which is also an implication of the monarchical influence in Ethiopian Christianity (Binns 2017:43). Frumentius is said to have sought out and empowered the exotic Christian mercantile community (Kaplan 1982:28). This would be possible in the face of the cosmopolitan nature of the port of Adulis (Bowersock 2013:30; Periplus 4; Casson 1989:51, 52). This, however, also implies that there was need for much foreign contact in establishing the native Christianity, a fact that can be rebutted in the perspective of the apostolic connections (Ac 8:26-38; Rukuni \& Oliver 2020). Aggregately, however, the narrative entrenches the significance of the maritime links of Aksumite-Ethiopia in the Christianisation of its country. A point already noted corresponded to these events when Ezana becomes of age Aedesius left for Tyre and Frumentius Alexandria from where he received the appointment of first Bishop of Ethiopia at the hands of Athanasius (Jones \& Monroe 1935:26-27). This element of the narrative is corroborated through the imperial inter-exchange of letters between Constantius and Ezana (Jamme 1966:34). This brings up the question regarding the conversion of Ezana and its dating.

\section{Questioning the conversion of Ezana}

There appears to be debate regarding the dating and actual eventuality of the conversion of Ezana to Christianity. This issue derives primarily from inscriptions and numismatics. In one of the earliest dated inscriptions, Ezana was said to have referred to himself as 'the son of Mahrem, who cannot be conquered by the enemy' (Littmann 1913:8-10, 18-28). The monarch also mentioned universal and native gods such as Astar, Meder and Baher. Most significantly, the evidence of the pagan practices of the king is derived from the coin inscriptions dated to have been from this era that bear the pagan symbols of the crescent and the disc (Kammerer 1926:157-159). In a coin, depiction attributed to Negus Endybis ca. 270/290 CE (Ezana's predecessor). The crescent and disc are notable features (Munro-Hay 1999). The crescent and the disc were depicted at the uttermost part of the coin above the frame of ears of wheat (Munro-Hay 1999). The disc and the crescent are a common inscription in southern Arabia and Ethiopia, thereby implying an interexchange of civilisation (Phillipson 2012:91).

Relatedly, the coin of Ezana was characterised by the crescent and the disc symbol. These are deduced as pagan symbols that relate to native religions (Munro-Hay 1999). The arguably earliest proof for the change of religion by the monarch Ezana is a monumental Geez inscription celebrating victory over the Nobatians (Kammerer 1926:157-159). 
Ezana in this inscription honoured '... the Lord of heaven ... his creator ... Lord of all' (Littmann 1954:121). There had been controversy as to the precise nature of the conversion of Ezana whether he was converted to Christianity, some vague monotheism or rather Judaism (Kaplan 1982:29). This was premised on the perceivably vague references to the heavenly and creator deities by Ezana.

Another argument placed him as Jewish, whilst another viewpoint hinted on the blended practice of Jewish Christianity within Ethiopian Christianity (Isaac 1972:242). The explicit and networked nature of Ezana's Christianity was, however, clarified by the Greek inscription that read:

In the faith of God and the Power of the Father, and the Holy Ghost who have saved my kingdom. I believe in your son Jesus Christ who has saved me. (Anfray, Caquot \& Nautin 1970:266)

The claims regarding the explicit nature of the inscription are substantiated in the statement that reads more like a Lukan-Acts new believer confession; similarly, the use of the Greek language has multiple suggestions. The use of Greek within the inscription might have been an appeal to the rest of Christian tradition as represented by Hellenic Alexandria; alternatively, it could have been a solidarity appeal to foreign contacts who were prevalent courtesy of the cosmopolitan nature of the port of Adulis (Christian Topography III 65; Wolska-Conus 1968-73, 1:502-505; Cosmas Indic., Topogr. Christ. 2.57-59; Conti-Rossini 1927:179-212; McCrindle 1897:93-98). Arguably, the view that assigns the perceived vagueness to the blend of Christianity and Judaism in the concoction of Jewish Christianity holds substantial ground as explored in this research (Isaac 1972:242).

\section{Complex political-religious matrix}

The complexities regarding the non-explicit reference to Christianity in Ezana's inscription has led on to another conclusion by certain scholarship. Kobischanow offers a theory where he suggests that there were two Ezanas (Kobishanow 1978:156). Consequently, the first inscription would be attributable to his father and predecessor Ezana I, and correspondingly, he would be Ezana II, the one to whom can be traced the explicitly Christian declaration. This argument, however, lacks substance in the manner in which it evades the assertion by Caquot and Nautin that both inscriptions are an allusion to the same military victory in Nubia (Kaplan 1982:30). Sergew offers a more relatable theory, one that positions Ethiopia amidst 3rd and 4th century religious-political realities (Sergew 1972:104).

Sergew emphasises the manner in which Christianity had passed firstly through the stage of enculturation amongst lower classes within the Roman Empire and correspondingly landed in the top echelons of state (cf. Salzaman 2002). The conversion of the Roman aristocratic class was an event that followed after the multiplicity of peasant and low-class faith. In contrast, however, the Christianisation of Ethiopia even when attributed to a dual influence of apostolic Christianity as per Lukan-Acts and the Theodoret-Rufinus accounts implies the preliminary conversion of aristocratic figures. However, the study accedes to the order of the Aksumite conversions as reflective of Ethiopian religious tradition from the account of Queen Makeda and her contact with Solomon (1 Ki 10:1-29; Kebra Naghast 25-32, Budge 2000:21-33). Agreeably, the religious histories of Ethiopia ascribe eminence to royal confessions of faith. The continuum of events in Ethiopian Christianity, in respect of the resistance of natives against conformity to the Jesuit catholic faith during the reign of Suseynos, proves the interconnectivity of the political conversions and the Christian sociocultural complex in Ethiopia (eds. Boavida, Pennec \& Ramos 2011:242; Caraman 1985:80, 94; Hassen 2015:276, 307).

Whilst the previously established notions are aggregately substantial, the other elements argued by the proponents of this view are relatively disputable. Sergew asserts that it was because there was an entrenched traditional paganism within Ethiopia; the King was subtle in his declaration of faith (Sergew 1972:104). Therefore, Ezana who laid claim to a divine rule of governance would not disassociate himself from the source of his unchallenged political power, his affinity to the pagan Mahrem and other local deities (Sima 2007:661-662). The declaration Lord of Heaven is thereby to be understood as to have been a commonly held allusion to pagan gods within Ethiopian society (Trimingham 1965:105).

The precedingly denoted view aggregately detaches Ethiopia from its complete religious tradition, for example, where was the Judaism of the Makeda-Menelik dynasty (cf. Budge 2000; Ullendorff 1956:217); the Ethiopian Eunuch proves as substantial evidence of an explicit practice of the Judaic faith in Ethiopia (Ac 8). Presumably, the hole poked into the alternative theory suggested here is mainly derived on the argued lack of archaeological connection between these two definitive events of aristocratic explicit practice of Judaism and the 1st-3rd century Ethiopian religious history. Regarding the use of the phrase 'Lord of Heaven', there is a possibility for another deduction altogether consequent of a word study of the phrase. If the Judaic background of Ethiopian religious complex is to be inferred as a concrete assumption upon the deductions regarding the perceived pre-Christian state, it would be noteworthy to establish the Hebraic links that could have been consequent in the inscriptions of the King (Littmann 1954:121).

\section{The Lord of Heaven-Lord of hosts: Derived Hebraisms}

A substantial case can be made for the declaration Lord of Heaven to be deduced as intrinsically Hebraic and therefore Jewish rather than for it to be taken as pagan. Whilst the reference to Mahrem and other pagan deities has been noted however, ground can be found for reference to the Jewishness of the Ethiopian religious practices. The use of the phrase 'Lord of Heaven' in military settings within the Old Testament (Tanakh) can be rightly inferred in respect of Ezana's inscription. The Lexham bible dictionary offers the following definition to the word hosts which is interchangeable with heaven at times. 
The word (hosts) צִ (Hebrew) recurs within the Old Testament; interestingly, at this stage it would be notable to put into perspective the affinity between Ge'ez and Hebrew (Ullendorff 1956:240; McMains 2016). The word interchanges between human and angelic armies; alternatively, it also functions as a reference to heavenly bodies as objects and exhibits of God's sovereignty and authority. Either way, the aggregate intention of the phrase is a power statement as this phrase and its use usually recurs in statements of Divine sovereignty and magnificence as shadowed in the majesty of the creation.

Isaiah 40:25-26 (Hebrew):

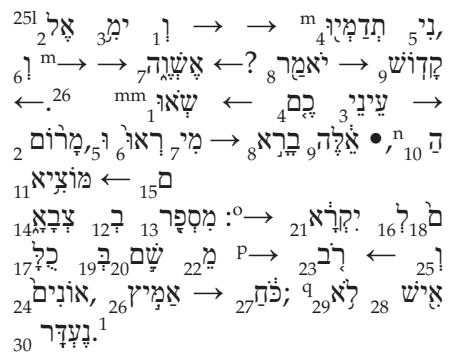
${ }^{25}$ To whom then will ye liken me, or shall $I$ be equal? saith the Holy One. ${ }^{26}$ Lift up your eyes on high, And behold who hath created these things, That bringeth out their host by number: He calleth them all by names By the greatness of his might, for that he is strong in power; Not one faileth

Isaiah 40:25-26:

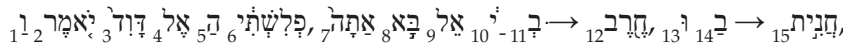

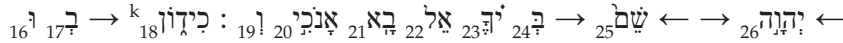

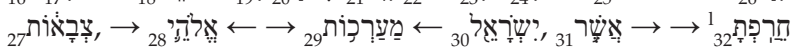

1 Samuel 17:45 (Heb):

${ }^{45}$ Then said David to the Philistine, Thou comes to me with a sword, and with a spear, and with a shield: but I come to thee in the name of the Lord of hosts, the God of the armies of Israel, whom thou hast defied.

1 Samuel 17:45:

The two passages above enhance the argument regarding the possibility of the statement Lord of Heaven being Hebraic religious-martial semantics. Whilst the first one is a reference to the use of the term in conjunction with heavenly bodies, the second one is an excerpt of the battle narrative between David and Goliath. One common feature between the two is the emphasis upon the implied power and majesty of the צִבְָאוֹ / YHWH SeBa' oTH [Lord of Hosts], who commands his צִבְ /SeBaa [Hosts]. Therefore, the Hebraic understanding that Divine appellations that revere God's sovereignty over the heavenly domain, alternatively implied his military majesty as expressed by his angelic army, were not foreign to Ethiopia. In a monumental inscription which was a celebration of military victory, the recognition of the Lord of Heaven who was alternatively the Lord of all armies would be befitting.

The preceding observation can arguably be so if the Judaic background of Ethiopia is to be considered as fact rather than legend, after all the narrative of Queen Makeda's visit to Israel is as old and mutually authentic as evidence for the Davidic dynasty (1 Ki 10:1-29; Mt 12:41; Kebra Naghast 25-32, Budge 2000:21-33). If Judaic tradition was part of Ethiopia's religious matrix as perceivable in the review of the biblical historical monograph of Lukan-Acts's account of the Ethiopian Eunuch, it thereby follows that the Lord of Heaven was an ascription to the Lord of Hosts. The explicit references to pagan deities, an undisputable fact, can be explained in the perspective of relative syncretistic royal pagan conversions such as the one of Constantine (Kee 2017:23-24; Kreider 2013:49; Lee 2006:170; Zos. HN 4.36.4, Ridley 1982:87). The explicit nature in which this appellation in Jewish thinking is directly relatable can also be observed in a reflection of another significant battle account in Jewish biblical history. In the narrative regarding an epiphany in the book of Joshua as the Israelites prepared for an offensive on Canaanites, a divine being appears who is identified by the title 'Captain/Commander of the Lord's

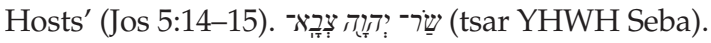

Notable observations can be derived from the inscriptions RIE 190 and 271 that are argued to be a reproduction of the Ge'ez text decoded as RIE 189 (Phillipson 2012:61). The inscriptions are a recount of the Noba and Kasu battles. There are several divergencies between the mentioned slabs with the annotated source slab platform such as height and width. The difference, however, can be because of the reason that whilst other inscriptions were composite to an actual throne or larger monument, the earlier slab was part of a monumental smaller throne such as the Adulis throne monument (cf. Bowersock 2013). The distinctive feature that is a derivate from these inscriptions RIE 190 and 271 is their extensive detailing of the military campaign and the prevalent religious atmosphere at the respective moment. Interestingly, the inscriptions mention the departure of the king from Aksum to have been on a Saturday the 8th of Magabit; archeologically, the aggregate years are 349, 355 and 360 CE (Phillipson 2012:61).

The emphasis upon the fact that it was on a Saturday when the king embarked on his military campaign is religiously significant. It has to be noted, however, that as per second temple impressionism, it would be defilement of the sabbath to merely defend one's own life in the case of an attack (1 Macc 2:32-41). Looking at the preceding notion relatedly, it seems there was a conflicted understanding regarding the matter (Josephus Antiq XII.6.2, XIII.1.3; O'banon 2016: 651-652, 674, 703). When viewed from the Tanakh - in this case a more appropriate informant source for Ethiopian Judaic practice - war on a sabbath can be arguably orthodox at divine command.

The account of Joshua and the city of Jericho imply a siege which can be characterised as a religious-military offensive which consummated on a 7th day (Jos 6). Whether the specific day of the final offensive was a Sabbath day or not that would be another discussion; however, it would be noteworthy to acknowledge the preservation of the weekly cycle in the 
Judaic practice of Sabbath keeping (Ex 20:8; cf. Heschel 2003). Therefore, in the perspective of the above, this would imply that the reference to Saturday in Ezana's inscription is a direct allusion to the religious nature of his battle. That is, the battle would take place on the Lord of Heaven's day and thereby consummate with a divinely sanctioned victory.

The religious nobility of Ezana's military offensive is further derived and enhanced by the DAE version of the inscription, DAE11 line 8 (Kaplan 1982:32). In this inscription, there is an echo of religious propaganda as denoted by the motive of the incursion to have been provoked by the plea for assistance from the Mangiatho, Chasa, Tiaditae and Bareotae (Kaplan 1982:32). Therefore, in a Hebraic deduction, the king Ezana was acting as a typical representative of Israel Abraham who waged a rescue attempt for several princes (Gn 14:14).

The claims may be argued as over-assumptive, inconsistent with authentic historical deductions. As one may even argue that this is eisegetic, that is, reading abstract meaning into the historical evidence derived from the inscriptions (cf. Rodinson 1964:238-245). In the defence of the theories proposed in the research reference to Isaac (cf. 2013) and Ullendorff's (cf. 1956) assertion that there should be evidence for the symbiotic expression of Judaic-Christian tradition in the Ethiopian religious matrix. Therefore, basing on the historicity of the Ethiopian-Israelite connection, inferring Judaic impressionism upon Ethiopian history is a logical possibility.

\section{Compromise of a royal conversion}

Schneider insists that the inscription DAE 11, whilst it can be deduced as not explicitly pagan maintained certain elements that resonated with the traditional religion (Schneider 1987:48). Thereby from this perceived ambiguity, scholars have raised queries with categorically external sources for the evidence of the Christianisation of Ethiopia. In the class of external sources would be historical texts attributable to ecclesiastical figures, Rufinus (Amidon 1997) and Athanasius (ed. Schaff 1885b). Some of the arguments proposed consequent of this critique are not as concrete, such as the allusion to the miscomprehension of India ulterior and IndiaAbyssinia (Moffet 1998:38). It would only take a cross reference with Athanasius' letter, for example, to ascertain that the agenda sought by the leader of Byzantine-imperial Christianity was ecclesiastical conformity in Alexandria and extendedly Aksumite territory (Rukuni \& Oliver 2019:2). In addition, there is an argument that there were two Ezanas, extendedly, that the Christian coins attributed to him are for a latter monarch (Kobishanow 1978:156).

Lastly, there was an argument that Ezana was not Christian, hence the covert overture to Ezana, by Constantius to undo ecclesiastical hierarchies that were attributable to Athanasius (Haas 2008:103). The attributed letter lacks clarity as to the nature of Athanasius' crimes; hence, some infer that this categorises Ezana as one not privy to the complexities of nicene-orthodoxy and polities (Schneider 1987:48). The preceding can be rebutted in the perspective of the fact that this could have served to only discredit the case of Constantius, as it entailed his political interests in the matter. Given that this was aggregately an instruction to another sovereign, concession had to take the appearance of mutual interests rather than submission (Hendrickx 2017:6-8; Letsios 1988:165-169). There observably is a notable theme regarding the pagan form of the writings and perceivably how they mirror Constantine's political conversion (cf. Haas 2008).

\section{Constantinian syncretistic formula}

The conversion of Constantine infers respective insights upon the current discussion. A retrospective review of Constantinian religious-political policy, especially towards the aristocracy, shows a trajectory of Christian conversion with pagan elements (Salzaman 2002:188; Lee 2006:170). This perhaps fills into the argument that pertains the continuation of 'formulas inherited from paganism ... in addition to the non-explicit Christian terms' (Schneider 1987:49). Deductions from the aforesaid proposition imply a covert attempt by the monarch to incite the trajectory towards Christianity. This had to be accomplished in a subtle manner that would not rattle the religious-cultural matrix of the country it would seem. In the perspective of the proposed view regarding the Judaic nature of the DAE 11 inscription, as conformant with the entrenched nature of Judaic practice in Ethiopia's religious-cultural matrix, there is a theory affirming the explicitly monotheistic incline of the respective inscription.

Rahlfs reviewed DAE 11 against pagan inscriptions so as to ascertain the departure from the traditional format of monumental inscriptions (Rahlfs 1916:287-305). Rahlfs asserts that despite the omission 'the Holy Spirit or the Son', the emphasis made within the inscription regarding the Lord of the Heavens and Master of the Universe as the Lord Almighty, who handed victory over to the king and conquered on the king's behalf, echoes strongly for a monotheistic faith. The emphasis in this case was upon the monotheistic element of the monarch's faith. Alternatively, this could have been a compromise solution for pagans, hence the implied neutrality, such that the monarch would not appear as divergent from traditional religion. The perceivable ambiguity and the use of Greek (which could possibly have been to veil the inscription from much of the local population) in the parallel inscriptions relating to the same battle, however, does not consist enough ground for the preceding theory (Schneider 1987:50). There is an explicit inclination to monotheism that shows a divergence from the established 'pagan' traditional religious beliefs. The discussion regarding transition in Aksumite inscriptional practice would be enhanced by a parallel review of Byzantine and Aksumite diplomatic practice. Another subject that enhances the retrospective review regarding the Christianisation of Ezana is the dating of the monarch.

\section{The historicity of the legend}

Munro-Hay defended the timing of the Ethiopian Christian odyssey in which the Syrian Christians Meropius, Aedesius 
and Frumentius made contact with Ethiopia (Munro-Hay 1988:111-127). This was done against the backdrop of contra-theorem that built from the perceived absence of the name Ezana in the native traditions of the Christianisation of Ethiopia. Altheim and Stiehl argued that Ezana is to be dated to the 5th century (Altheim \& Stiehl 1976:471-479). Similar endeavours to re-date and suggest more than one Ezana were done by Pirenne (1975:73-82). Schneider and Munro-Hay compose part of the scholarship that assert for a contemporary reality of Frumentius, Aedesius and Ezana in 4th century Christendom basing on numismatics and inscriptions. Arguably, the Ethiopian traditional sources such as the Synaxarium derive from Rufinus (ca. 345-410) and Socrates (ca. 380), authors of ecclesiastical histories. Derivate of this dynamic there is a preservation of the names of Meropios, Feremnatos and Aedesios/Sidrakos, that is, the equivalents of Meropius, Frumentius and Aedesius (Budge 1928:1164-1165).

Retrospectively, even the native traditions derive extensively from the reality of maritime inter-exchange between Ethiopia and the Mediterranean world (Geographica 2.5.12, ed. Jones 1917:455; Topogr. Christ. 2.59-66, McCrindle 1897:98-116). The preceding assertion is confirmed by the emphasis upon the interconnection of Adulis port with the route that reached India and how this directly implied the arrival of Syrian Christians upon Ethiopian territory.

In addition, ensuing controversy pertains the allusion to Frumentius and Aedesius as Abreha and Atsbeha, this has been debunked in the favour of theorem assigning these 'epithets' to possibly Ezana and Sazana or rather latter monarchies Kaleb as Ella Atsbeha and Abreha an Aksumite client monarch in Himyar (Ullendorff 1949:61-62). Possibly the epithet Ella was an indication of the monarch's new religion of Christianity as it is mainly traceable to Ezana (Munro-Hay 1988:114). In the period preceding the rise of Constantine when the Roman empire was characterised by civil war and diminishing borders, Aksum within its region was rising to political and economic eminence (cf. Bowersock 2013; Potter 2013). Against the preceding background as an autonomous economic and political nation, Aksum minted its own coinage (Munro-Hay 1984). The prominence prevalent with Ezana is traceable from his predecessors who can be referenced against the locus of the Throne monument of Adulis (Robin 1981:315-339). Amongst those monarchs, some make explicit claim of incursion into Arabia. Dually, some expanded Aksum within the African mainland (cf. Bowersock 2013; Phillipson 2012). It would only take a retrospective approach to review the possible influence of apostolic Christianity upon negus GDRT (Ezana's distant predecessor) or his predecessors given his chronological placement within the 1st and 2nd century.

Given the prominence of latter kings such as Kaleb who allied with Christian Byzantium and made war upon Himyar, basing on John of Nikiu's chronicles dateable to 7th century (during Justinian's reign), there has been a deduction on the Christianisation of Ethiopia as at that period (The Chronicle of John XC.78; Charles 1916:142). This does not hold, however, in the face of the record of AksumiteHimyaritic clerics such as AWFRFYS (Urfrf) mentioned in the Book of the Himyarites who was evidently active before the war (Shahid 1971:63). According to Petrides, 333 CE can be assigned as the date for the royal proclamation for the acceptance of Christianity in Aksum (Petrides 1972:208232). This thereby implies a erminus post quem [an earliest date] for all material with the royal Christian titulature such as the inscriptions and coins. Munro-Hay also asserted that the variations in the names of the Negus as Ezana or Ezanas cannot be used as substantial ground for the existence of two Ezana (Munro-Hay 1988:121). Basing on the variations of transcriptions of previous inscriptions into Greek such as the Beja war monument where the brothers of the monarch

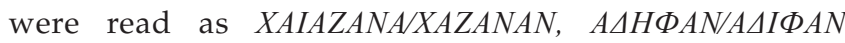
(Sazana and Adiphan), respectively, Munro-Hay argues that this is a matter of idiosyncratic decoding by varying scribes (Munro-Hay 1988:121).

Thereby in full view of the preceding observations and comprehensive examination of numismatic and inscriptional data, Munro-Hay thereby corroborated a chronological narrative. The proposed narrative reads out as the explored account of Rufinus' ecclesiastical history. Notable in the chronology is that Munro-Hay suggests that at $325 \mathrm{CE}$, Ezana had become full sovereign, and his brothers were in charge of the military. This extendedly explains the mention of possible coregent Sazana in Constantius' address (cf. Hendrickx 2017). Significant inscriptions dating the eminence of the monarch are derived from monuments celebrating military campaigns. The Beja war, the Agwezat and Afan campaigns monuments are categorised as earliest preserved inscriptions, and though pagan they are attributable to Ezana (Munro-Hay 1988:121). The various inscriptions are recorded in Greek, 'psuedo-Sabean', and $\mathrm{Ge}^{\prime} \mathrm{ez}(\mathrm{DAE} 4,6,7,9,10)$. The translingual nature of the Aksumite monuments entrench the idea regarding interconnected nature of Aksumite geo-politics and by extension religion. Although Greek can corroborate the impression of Ptolemaic aristocratic practice in BCE Adulis region, pseudo-Sabean affirms the sovereign claims over Himyar and lastly Ge'ez the affinity to Judaic elements. By inferring the preceding notions upon the royal inscriptions, the Christian legend of the monarch Ezana thereby fits into the extensive narrative of Ethiopia's global religiouspolitical history.

Regarding DAE 8, another early inscription that mentions the 'Bisi' title, Munro-Hay suggests that this preceded Ezana and belonged to Ousanas Bisi Gisene also known as Ella Amida his predecessor (Munro-Hay 1988:122). The Christian inscription DAE 11 belonging to Ezana which also comes in different languages, Greek, pseudo-Sabean and Ge'ez has a religious formula which incites multiple deductions. As a factor of contrast, whilst the inscription's Ge'ez version is said to be vague in minimum and pagan-neutral in the extreme, there is an argument for its affinity to Judaic 
expressions of Deity as already argued. Correspondingly, the Greek and pseudo-Sabaean scripts are the more explicit ones; however, the Sabaean one is also characterised by a cross that is similar to 4 th century dated cross engravings on bronze coinage, bronze belt buckle (Schneider 1974, 1976). Aggregately judging by the dating of monumental inscriptions and affiliated material Munro-Hay thereby concludes that Ezana's reign as a pagan monarch stretched from ca. 325-333 CE approximately (1988:122). This being verifiable archaeologically when synthesised with the dynamics in early Christianity could possibly explain a relatively detached state of Aksum from the Nicene council a signal moment in Christian orthodoxy's religious-polities.

In a related argument, Ezana is deduced as monophysite by others; therefore, his Christianity is dated to be post $451 \mathrm{CE}$, thereby making him a 5th century phenomenon. Whilst there are elements of Aksumite imperial Christianity that synthesise with monophysitism given eastern influences as explored and will be entrenched further, the affinity to Nicene Christianity is also apparent in inscriptional evidence where Ezana professes a Nicene like Christology (Anfray et al. 1970:260-274).

\section{Christianisation of Ethiopia as an archaeological discussion}

Phillipson asserts that a synthesised deduction from numismatics, textual and epigraphic evidence affirms the Christianisation of Ezana as a 4th century phenomenon (Phillipson 2012:98). Before the Christianisation of Ethiopia as signalled by the royal declaration by the monarch Christianity was a religion for the foreign community according to Philipson, presumably this view implies the spread of Christianity to Aksum to have been only incidental of the inter-exchange courtesy of the trade routes. Phillipson argues that this could have been from the appointment of Athanasius as patriarch to the dating of the letter from Constantius II in the period 328-357 CE (Phillipson 2012:98). This complies with the proposed terminus that has been deduced as 333 CE. However, notably here Phillipson denotes that this is 333 EC (i.e. according to the Ethiopian Calendar).

Some have deduced the date to not be literal but rather symbolic (Sergew 1997:3). Just as the emphasis upon the 8 of Megabit being a Saturday, when the King Ezana went for a war which afterwards was impressed with an aura of imperialreligious political definition (Phillipson 2012:61). The Ethiopian calendar diverges with a backlog of 7 years behind the Gregorian calendar (Fritsch \& Zanetti 2003:668-672). This thereby implies 333 EC becomes ca. 340 CE. When making the appointment of Athanasius and correspondingly that of Frumentius a reference point in the dating of Aksumite Christianisation, ecclesiastical polities define the whole narrative. The preceding observation builds credence against the eventualities of 4 th century Christianity.
The Christianisation of Ethiopia by virtue of derivation from Alexandria becomes positioned amid Nicene orthodoxy political dynamics (cf. Barnes 2011:141; Rukuni 2018:138-142). The continuum resultant from ecclesiastical divides at the Nicene council saw the juxtaposed demise and elevation of Athanasius, a deputy of Alexander (Behr 2004:157). The fortune of Athanasius as the rest of the clergy was aggregately a factor of imperial favour or disapproval (VC 2.64-72, Barnes 2011:122; ed. Schaff 1885a:779-783). Hence, consequent of the imperial role in the functionality of the episcopacy, the death of Constantine the great in $337 \mathrm{CE}$ was a hallmark that redefined the ecclesiastical political terrain. Athanasius had been liable to favour and latter disfavour consequent of the switching fortunes of Arius' allies, such as the exaltation of Eusebius of Nicomedia in 338 CE (Theodoret HE 1.13,18; ed. Schaff 1885b:111, 121). For Phillipson, the description in Rufinus that claims nuper sacerdotium susceperat [recently received the priesthood] should not always be deduced as implying the initial elevation of Athanasius to the episcopal role (Amidon 1997:20), this could also be understood to the assignment of a clerical role to Frumentius (ed. Stevenson 1966:35). This would be an attempt to find resonance with Aksum within the sources that record the history of imperial Christianity.

The version deduced from the Ethiopian Synaxarium inclines towards a focus on the re-appointment of Athanasius rather than the elevation of Frumentius, thereby implying a later date for the role of Frumentius. Budge's translation mentions the 'restoration' to office, whilst Grillmeier denotes it as a 'new office', all these phrases are a reference to Athanasius' elevation or rather re-elevation and possibly not the appointment of an Aksumite episcopate (Budge 1928:1165; Grillmeier 1996:299-300).

Phillipson further investigated the intrinsic and historical use of the term susceperat (he had undertaken), that is the universal use of the word in its contemporary context. The preceding use of the word within the script of Rufinus would ultimately imply the latter dating of the appointment of Frumentius and therefore the latter dating for the Christianity of Aksum. Phillipson noted, however, that this clause was not in the Greek texts of Theodoret and Sozomen, which as he argues are deduced directly from Rufinus' Latin text (Phillipson 2012:99). The indication would be this phrase was an edition by a copier-redactor later on. However, a notable fact is that Socrates Scholasticus' version contains the phrase.

There is an argument, however, for a 337 appointment of Frumentius; this has been claimed as far back as the 17th century CE (Phillipson 2012:99). Notably that Rufinus himself might have actively incited the impression that would affiliate the appointment of Frumentius with the reign of Constantine the great (Thelamon 1981:62). This assertion although challenged as observed earlier has significance in the corroboration of ecclesiastical historical accounts. To locate the Christianisation of Aksum within the momentum created by the establishment of imperial 

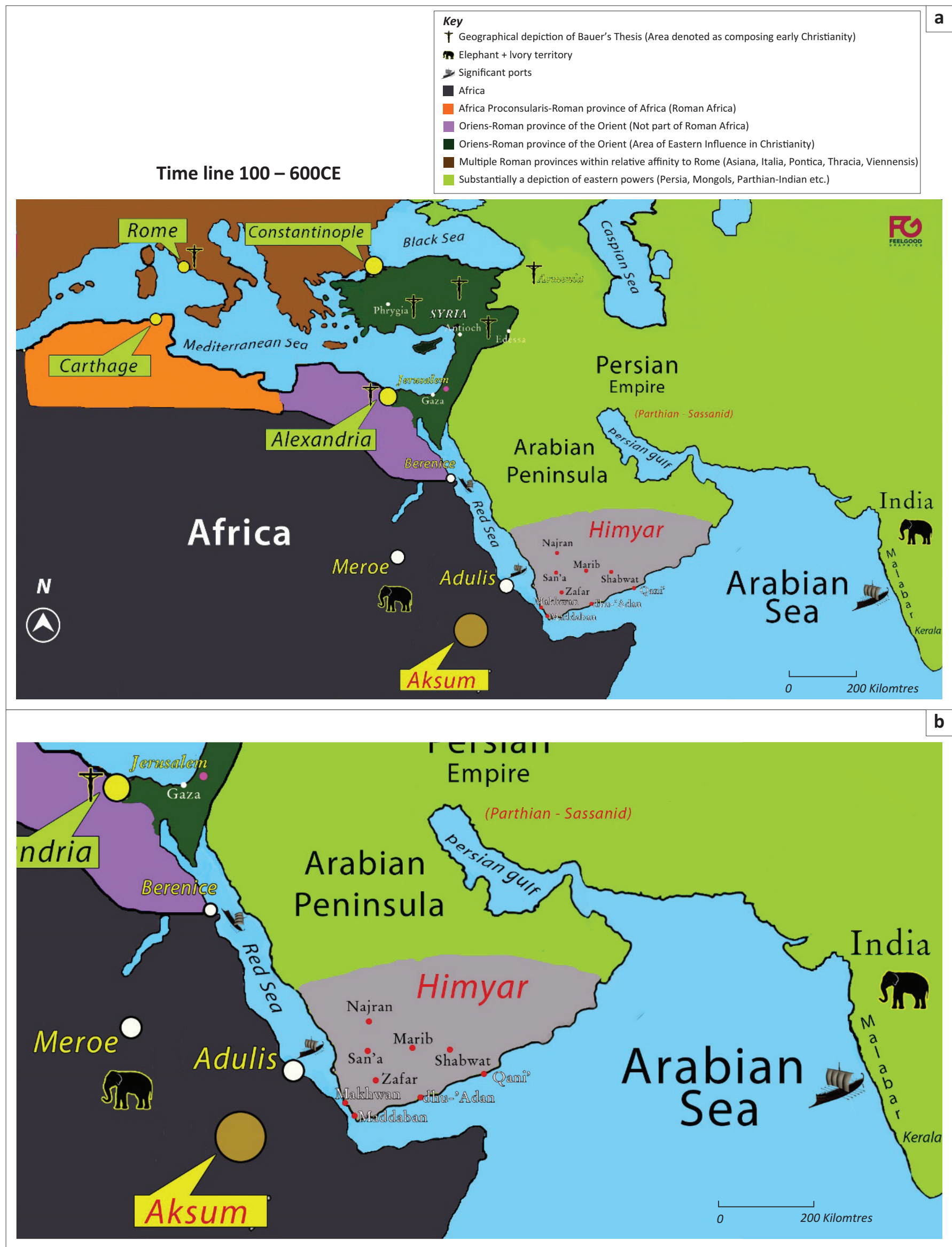

FIGURE 1: Map illustrating areas and dynamics in the discussion underneath is a zoomed excerpt. 
Christianity is overly significant. This extendedly attaches the narrative of Ethiopian Christianity within the complex matrix that was consequent of Nicene orthodoxy as a factor of imperial ecclesiastical dynamics. This theory gains further credence in the perspective of the ensuant ecclesiastical political nature of the relations between RomeByzantine and Aksum.

Phillipson argues that apart from the numismatics, inscriptions, further excavation has not substantiated the Christianisation of Ezana at an early stage (Phillipson 2012:99). The support from additional archaeology can be deduced in changes of outwards trappings of graves; notably however, this observation was a royal phenomenon (Chittick 1974). Phillipson asserts that Aksumite Christianity can only to be traced to places that were under direct influence of the monarch (Phillipson 2012:99). This he argues to have been the case with even some elites, as established by the Anza and Matara stelae which although dated to be latter centuries after $340 \mathrm{CE}$ are characterised by the crescent-and-disc symbol (Anfray 1963:105-108; Fiaccadori 2007). However, it should be noted that the basis for dating the Anza and Matara stelae is purely epigraphic comparison; hence, there is a possibility for the stelae intrinsically belonging to the era preceding Christianity (Phillipson 2012:100).

As regarding some of the burial evidence substantiates a case for a syncretistic practice of blending Christianity with the traditional religion as seen in the Brick Arches tomb c 4th century CE (Phillipson 2000:31-133). The previously mentioned tomb held funerary pottery that was embellished with a synced cross-crescent and disc symbol. However, as noted, these were all realities amongst the aristocratic classes; the more concrete evidence for the national adoption of Christianity is derived from ethnoarchaeology. Ethnoarchaeology involves the investigation of the social organisation, ethnological features of a current ethnicity through its material culture so as to connect with the past civilisations.

The most concrete evidence for the general spread of Christianity amongst the populous would be the crossshaped decorations on domestic pottery (Phillips 2000:77, 282; Anfray 1963:105-108). These markings became prominent only towards the end of the 5th century and beginning of the 6th century. Another piece of funerary evidence is a tombstone dated to have been from the 6th century. It was discovered at Gumala, North of Aksum, which was carved with a Greek inscription and dually a cross. The inscription identifies a 10-year-old as the buried; Phillipson asserts that this implies a Greek speaking community amongst the native Christians of Ethiopia (Fiaccadori 2007). The existence of a generally Hellenised form of Christianity cannot be completely ruled out in the perspective of the Alexandrian contacts and the existence of migrants from Egypt as a consequent of the maritime travel.

\section{Conclusion}

Ezana's acceptance of Christianity and the Christianisation of Ethiopia is aggregately capable of being established archeologically and historically it seems. Debate surrounding the precise chronological order of events in the religious history of Ethiopia, basing upon the absence of explicit Christian evidence, is an established opinion. However, when inferring the Judaic-Christian connection of Ethiopian history as a referral locus, revisionist conclusions are possible as to the reality or complete nature of the Negus' conversion. Identifying and locating Ezana amidst the dynamics of early Christianity, in the perspective of the reality of Constantinian dynamics and their derived influences and parallels, furthers the development of an integrated narrative of Church History, one that appropriately assigns significance and relevance to an emergent Christian power Southern of the Roman Empire. The main challenge that entails a failure to reconcile Ethiopia's ancient Aksumite Judaic religious traditions and the emergent Christianity remains mostly archaeological. Ezana, the person when established as fact, adds to the building blocks from which the almost deemed legendary narrative of Ethiopian Christian history derives. Ezana when considered in tangent with the influences of his encounter with the Syrian clerics, Byzantine emperors enhance the comprehension of Ethiopian religious statecraft.

\section{Acknowledgements Competing interests}

The author has declared that no competing interests exist.

\section{Author's contributions}

I declare that I am the sole author of this research article.

\section{Ethical consideration}

This article followed all ethical standards for a research without direct contact with human or animal subjects.

\section{Funding information}

This research received no specific grant from any funding agency in the public, commercial or not-for-profit sectors.

\section{Data availability statement}

Data sharing is not applicable to this article as no new data were created or analysed in this study.

\section{Disclaimer}

The views and opinions expressed in this article are those of the author and do not necessarily reflect the official policy or position of any affiliated agency of the author.

\section{References}

Altheim, F. \& Stiehl, R., 1976, Die neue griechische Inschrift 'Ezanas von Aksum, 'Klio' 58, 1976, pp. 471-479, Degruyter, Berlin. https://doi.org/10.1524/klio.1976.58.12.471 
Amidon, P.R., 1997, The Church History of Rufinus of Aquileia, books 10 \& 11, Oxford University Press, New York, NY.

Anfray, F., 1963, Première campagne de fouilles à Matara (Nov. 1959-Jan 1960) Annales d'Ethiopie 5, 87-166, viewed 15 December 2019, from www.persee.fr/ doc/ethio_0066-2127_1963_num_5_1_1332.

Anfray, F., Caquot, A. \& Nautin, P., 1970, “'Une nouvelle inscription grecque d'Ezana, roi d'Axoum," Documents pour servir a l'historie des civilisations ethiopiennes, 2 (1971), pp. 45-60', Journal des Savants 260-274, viewed 08 October 2019, from www.persee.fr/doc/jds_0021-8103_1970_num_4_1_1235.

Barnes, T.D., 2011, Constantine. Dynasty, religion and power in the late Roman Empire Wiley-Blackwell, Chichester.

Behr, J., 2004, The Nicene faith: Formation of Christian theology, vol. 2, St Vladimir's Seminary Press, Crestwood, MO.

Binns, J., 2017, The orthodox church of Ethiopia: A history account, I.B. Tauris, London.

Boavida, I., Pennec, H. \& Ramos, M.J. (eds.), 2011, Pedro Paez's History of Ethiopia, 1662,2 vols, The Hakluyt Society, London.

Bowen, G.A., 2009, 'Document analysis as a qualitative research method', Qualitative Research Journal 9(2), 27-40. https://doi.org/10.3316/QRJ0902027

Bowersock, G.W., 2013, The throne of Adulis: Red Sea Wars on the Eve of Islam, Oxford University Press, New York, NY.

Budge, E.A.W., 1928, The Book of the Saints of the Ethiopian Church (4 vols), Cambridge University Press, Cambridge.

Budge, E.W., 2000, The Queen of Sheba and Her Only Son Menyelek: Kebra Nagast, Ethiopian Series Cambridge Publications, ON.

Caraman, P., 1985, The lost empire: The story of the Jesuits in Ethiopia 1555-1634, University of Notre Dame, Notre Dame, IN.

Casson, L., 1989, The Periplus Maris Erythraei, Princeton University Press, Princeton,

Charles, R.H. (transl.), 1916, The Chronicle of John, Bishop of Nikiu, Oxford University Press, Oxford.

Chittick, H.N., 1974, Excavations at Aksum: A preliminary report, Azania 9, 159-205, Azania: Archaeological Research in Africa, Taylor \& Francis, Abingdon.

Conti-Rossini, C., 1927, 'Monete aksumite', Africa Italiana 1, 179-212.

Danto, E.A., 2008, Historical research, Oxford Scholarship Online, viewed 12 January 2018 from:http:/www.oxfordscholarship.com/view/10.1093/acprof:oso/9780195333060. 001.0001/acprof-9780195333060.

Fiaccadori, G., 2007, Nuova iscrizione greca da Aksum, La Parola del Passato 62, pp. 70-76, Gaetano Macchiaroli Editori, Naples.

Fritsch, E. \& Zanetti, U., 2003, 'Calendar', in S. Uhlig (ed.), Encyclopaedia Aethiopica, vol. 1, pp. 668-672, Harrassowitz, Wiesbaden.

Grillmeier, A., 1996, The Church of Alexandria with Nubia and Ethiopia after 451 (Vol. 2, part 4 of Christ in Christian Tradition), transl. O.C. Dean, Mowbray, London

Haas, C., 2008, 'Mountain constantines: The Christianization of Aksum and Iberia', Journal of Late Antiquity 1.1(Spring), 101-126.

Hassen, M., 2015, The Oromo and the Christian Kingdom of Ethiopia 1300-1700, James Currey, New York, NY.

Hendrickx, B., 2017, Letter of Constantius II to Ezana and Sezana: A note on its purpose, range and impact in an Afro-Byzantine context, Graeco-Arabica, 12, pp. 545-556.

Heschel, A.J., 2003, The Sabbath: Its meaning for modern man, Shambhala Library Boulder, CO.

Insoll, T., 2004, Archaeology, ritual, religion, Routledge, London.

Isaac, E., 1972, 'An Obscure component in Ethiopian Church History: An examination of various theories pertaining to the problem of the origin and nature of Ethiopian Christianity', Le Museon 85, 225-58, Editions Peeters, Louvain

Isaac, E., 2013, The Ethiopian Orthodox Tawahido Church, The Red Sea Press, Trenton, NJ.

James, M.R. (transl. and ed.), 1924, The Apocryphal New Testament, Clarendon Press, Oxford (this edition 2006, A. Muller trans).

Jamme, A., 1966, 'Sabaean and Hasaen inscriptions from Saudi Arabia', Studi Semitici, vol. 23, University of Rome, Rome: Institute of Near Eastern Studies.

Jones, A.H.M. \& Monroe, E., 1935, A history of Ethiopia, Clarendon Press, Oxford.

Jones, H.L. (ed. \& transl.), 1917-32, The geography of Strabo with an English translation, 8 vols., Harvard University Press (Loeb Classical Library), Cambridge, MA.

Kammerer, A., 1926, Essai sur l'histoire antique d 'Abyssinie, Librairie Orientaliste Pau Geuthner, Paris.

Kaplan, S., 1982, 'Ezana's Conversion Reconsidered', Journal of Religion in Africa, 13 101-109, republished in Bausi, A. (ed.), 2012, Languages and Cultures of Eastern Christianity: Ethiopian, pp. 27-55, Ashgate Publishing Ltd, Surrey.

Kee, A., 2017, Constantine versus Christ: The triumph of Ideology, Wipf \& Stock, Eugene, OR.

Kobishanov, Y.M., 1978, 'Axum', in H.J.M. Claessen \& P. Skalnik (eds.), The early state, Mouton Publishers, The Hague.

Kreider, A., 2013, “'Converted” but not Baptised: Peter Leithart's Constantine project', in J.D. Roth (ed.), Constantine revisited: Leithart, Yoder, and the Constantinian debate, pp. 25-67, Pickwick Publications, Eugene, OR.

Lee, A.D., 2006, 'Traditional religions', in N. Lenski (ed.), The Cambridge companion to the age of constantine, pp. 159-180, Cambridge University Press, New York, NY.

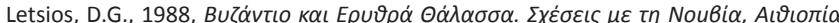

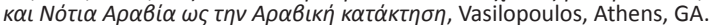

Littmann, E., 1954, An Old Ethiopic inscription from the Berenic Road, Journal of the Royal Asiatic Society, London.

Littmann, E., Krencker, D. \& Von Lüpke, T., 1913, Deutsche Aksum-Expedition Herausgegeben von der Generalverwaltung der Königlichen Museen zu Berlin, 4 vols., Reimer, Berlin.

McCrindle, J.W., 1897, The Christian Topography of Cosmas, an Egyptian Monk, Hakluyt Society, London.

McMains, M.J., 2016, 'Hosts', in J.D. Barry, D. Bomar, D.R. Brown, R. Klippenstein, D. Mangum, C. Sinclair Wolcott, et al. (eds.), The Lexham Bible Dictionary, Lexham Press, Bellingham, WA.

Moffet, S.H., 1998, A history of Christianity in Asia. Volume I. Beginnings to 1500, Orbis Books, New York, NY.

Munro-Hay, S.C., 1984, The Coinage of Aksum, Senior, Butleigh, Manohar, New Delhi.

Munro-Hay, S.C., 1988, 'The dating of Ezana and Frumentius', Rassegna di Studi Etiopici 32, 111-127. Republished in Bausi, A. (ed.), 2012, Languages and cultures of Eastern Christianity: Ethiopian, pp. 57-73, Ashgate Publishing Ltd, Surrey.

Munro-Hay, S.C., 1999, Catalogue of the Aksumite Coins in the British Museum, British Museum Press, London.

O'Bannon, K., 2016, Josephus: The complete works, Christian Classics Ethereal Library, Grand Rapids, MI.

Pearse, R. (transc), 2003, Ipswich, viewed 10 August 2019, from www.tertullian.org/ fathers/cosmas_02_book2.htm.

Petrides, S.P., 1971, 'Essai sur l'evangelisation de l'Ethiopie, sa date et son protagoniste', Abba Salama 2, pp. 77-104, University of California, Berkeley, CA.

Petrides, S.P., 1972, 'Essai sur l'evangelisation de l'Ethiopie, sa date et son protagoniste', Abba Salama III, pp. 208-232, University of California, Berkeley, CA.

Phillips, J.S., 2000, 'Contributions on pottery', in D.W. Phillipson (ed.), Archaeology at Aksum, Ethiopia, 1993-97, 2 vols., pp. 57-77, 303-337, 389-399, 435-438, 453-458, British Institute in Eastern Africa \& Society of Antiquaries, London.

Phillipson, D.W., 2000, Archaeology at Aksum, Ethiopia, 1993-97, 2 vols., British Institute in Eastern Africa \& Society of Antiquaries, London.

Phillipson, D.W., 2012, Foundations of an African Civilisation: Aksum \& the Northern Horn 1000 BC-AD 1300, James Currey, New York, NY.

Piovanelli, P., 2014, "'Orthodox" faith and political legitimization of a "Solomonic" dynasty of rulers in the Ethiopic Kebra Nagast', in K.B. Bardakjian \& S. La Porta (eds.), The Armenian apocalyptic tradition a comparative perspective essays presented in honor of Professor Robert W. Thomson on the Occasion of his eightieth birthday, pp. 688-705, Brill, Leiden.

Pirenne, J., 1975, L'imbroglio de trois siecles de chronologie aksumite, pp.73-82, DSHCE 6, Paris.

Potter, D., 2013, Constantine the emperor, Oxford University Press, Oxford

Rahlfs, A., 1916, 'Zu den altabessinischen Konigsinschriften', in Oriens Christianus, 6 , pp. 282-313, Harrassowitz Verlag, Leipzig.

Ridley, R.T., 1982, Zosimus New History: A translation with commentary, Byzantina Australiensia 2, Australian Association for Byzantine Studies, Department of Greek, University of Sydney, Sydney.

RIE, Recueil des Inscriptions de l'Ethiopia des periodes pre-axoumite et axoumite. Vol 1., Les documents and Vol 2 Les planches (Paris, 1991). Vol 3 Traductions et commentaires. A. Les inscriptions grecques (Paris, 2000).

Robin, C., 1981, Les inscriptions d'al-Mis'al et la chronologie de l'Arabia meridionale au III siècle de l'ere chretienne, 'Comptes rendus de I'Academe des Inscriptions et Belles-Lettres', Avril-Juin, pp. 315-339, viewed 16 May 2019, from www.persee. $\mathrm{fr} / \mathrm{doc} / \mathrm{crai}$ _0065-0536_1981_num_125_2_13841.

Rodinson, M., 1964, 'Review of Edward Ullendorff', The Ethiopians, Bibliotheca Orientalis 21(1964), 238-245. Jamet, A. (transl.), republished in Bausi, A. (ed.), 2012, Languages and cultures of Eastern Christianity: Ethiopian, pp. 163-178, Ashgate Publishing Ltd, Surrey.

Rukuni, R., 2018, The Schism, Hellenism and politics: A review of the emergence of Ecumenical Orthodoxy AD 100-400, UNISA, Pretoria.

Rukuni, R. \& Oliver, E., 2019, 'African Ethiopia and Byzantine imperial orthodoxy: Politically influenced self-definition of Christianity', HTS Teologiese Studies/ Theological Studies 75(4), a5314. https://doi.org/10.4102/hts.v75i4.5314

Rukuni, R. \& Oliver, E., 2020, Early Ethiopian Christianity: Retrospective enquiry in perspective of Indian Thomine tradition, HTS, Cape Town.

Salzaman, M.R., 2002, The making of a Christian Aristocracy: Social and religious change in the western Roman Empire, Harvard University Press, Cambridge, MA.

Schaff, P. (ed.), 1885a, Nicene and Post-Nicene Fathers. Series 2. Vol. 1: Eusebius Pamphilius: Church History, Life of Constantine, Oration in Praise of Constantine, Pamphilius: Church History, Life of Constantine, Oration
Christian Classics Ethereal Library, Grand Rapids, MI.

Schaff, P. (ed.), 1885b, Nicene and Post-Nicene Fathers. Series 2. Vol. 3: Theodoret, Jerome, Gennadius, \& Rufinus: Historical Writings, Christian Classics Ethereal Library, Grand Rapids, MI.

Schaff, P. (ed.), 1885c, Nicene and Post-Nicene Fathers. Series 2. Vol. 4: Athanasius: Select Works and Letters, Christian Classics Ethereal Library, Grand Rapids, MI.

Schneider, R., 1974, 'Trois nouvelles inscriptions royales d'Axoum', in IV Congresso Internazionale di Studi Etiopici (Aprile 1972), Problemi attuali di scienza e d cultura 191, I, pp. 767-786, Accademia nazionale dei Lincei, Roma.

Schneider, R., 1976, 'L'Inscription chretienne d'Ezana en ecriture sudarabique', AnnEth 10, 109-117, viewed 15 May 2019, from www.persee.fr/doc/ethio_00662127 1976_num_10_1_1164. 
Schneider, R., 1987, 'Notes on the Royal Aksumite Inscriptions', ('Notes sur les inscriptions royales aksumites'), Bibliotheca Orientalis 44, 599-616, Jamet, A., republished in Bausi, A. (ed.), 2012, Languages and Cultures of Eastern Christianity: Ethiopian, pp. 35-55, Ashgate Publishing Ltd, Surrey.

Sergew, H.S., 1972, Ancient and Medieval Ethiopian History to 1270, United Printers, Addis Ababa.

Sergew, H.S., 1997, The Church of Ethiopia: A panorama of history and spiritual life, 2nd edn., The Ethiopian Orthodox Church, Addis Ababa.

Shahid, I., 1971, The Martyrs of Najran: New Documents, Subsidia Hagrographica, 49, Brussels.

Sima, A., 2007, 'Mahrem', in S. Uhlig (ed.), Encyclopaedia Aethiopia, vol. 3, He-N, Wiesbaden, pp. 661-662.

Stevenson, J. (ed.), 1966, Creeds, councils and controversies: Documents illustrative of the history of the Church AD 337-346, Society for the Promotion of Christian Knowledge, London.
The Holy Bible: King James Version, 2009, Electronic Edition of the 1900 Authorized Version, Logos Research Systems, Inc, Bellingham, WA.

Thelamon, F., 1981, Païens et chrétiens au IVe siècle: I'apport de l'Histoire ecclésiastique de Rufin d'Aquilée, Etudes augustiniennes, Paris.

Trimingham, J.S., 1965, Islam in Ethiopia, Frank Cass, London.

Ullendorff, E., 1949, Note on the introduction of Christianity into Ethiopia', Africa 19(1), 61-62. https://doi.org/10.1017/S0001972000028941

Ullendorff, E., 1956, 'Hebraic-Jewish Elements in Abyssinian (Monophysite) Christianity', Journal of Semitic Studies, 1, 216-256, republished in Bausi, A. (ed.) 2012, Languages and cultures of Eastern Christianity: Ethiopian, pp. 122-161, Ashgate Publishing Ltd, Surrey. https://doi.org/10.1093/jss/1.3.216

Wolska-Conus, W., 1968-73, Cosmas Indicopleustès: Topographie Chrétienne, 3 vols, Editions du Cerf (Sources chrétiennes 141, 159, 197), Paris.

Yamauchi, E.M., 1972, The stones and the scriptures, Holman, New York, NY. 